The BMJ, London, UK Cite this as: BMJ 2020;371:m4425 http://dx.doi.org/10.1136/bmj.m4425

Published: 13 November 2020

\section{Covid-19: politicisation, "corruption," and suppression of science}

\author{
When good science is suppressed by the medical-political complex, people die
}

\section{Kamran Abbasi executive editor}

Politicians and governments are suppressing science. They do so in the public interest, they say, to accelerate availability of diagnostics and treatments. They do so to support innovation, to bring products to market at unprecedented speed. Both of these reasons are partly plausible; the greatest deceptions are founded in a grain of truth. But the underlying behaviour is troubling.

Science is being suppressed for political and financial gain. Covid-19 has unleashed state corruption on a grand scale, and it is harmful to public health. ${ }^{1}$ Politicians and industry are responsible for this opportunistic embezzlement. So too are scientists and health experts. The pandemic has revealed how the medical-political complex can be manipulated in an emergency-a time when it is even more important to safeguard science.

The UK's pandemic response provides at least four examples of suppression of science or scientists. First, the membership, research, and deliberations of the Scientific Advisory Group for Emergencies (SAGE) were initially secret until a press leak forced transparency. ${ }^{2}$ The leak revealed inappropriate involvement of government advisers in SAGE, while exposing under-representation from public health, clinical care, women, and ethnic minorities. Indeed, the government was also recently ordered to release a 2016 report on deficiencies in pandemic

preparedness, Operation Cygnus, following a verdict from the Information Commissioner's Office. 34

Next, a Public Health England report on covid-19 and inequalities. The report's publication was delayed by England's Department of Health; a section on ethnic minorities was initially withheld and then, following a public outcry, was published as part of a follow-up report. ${ }^{56}$ Authors from Public Health England were instructed not to talk to the media. Third, on 15 October, the editor of the Lancet complained that an author of a research paper, a UK government scientist, was blocked by the government from speaking to media because of a "difficult political landscape."7

Now, a new example concerns the controversy over point-of-care antibody testing for covid-19. ${ }^{8}$ The prime minister's Operation Moonshot depends on immediate and wide availability of accurate rapid diagnostic tests. ${ }^{9}$ It also depends on the questionable logic of mass screening-currently being trialled in Liverpool with a suboptimal PCR test. ${ }^{10} 11$

The incident relates to research published this week by The BMJ, which finds that the government procured an antibody test that in real world tests falls well short of performance claims made by its manufacturers. ${ }^{12}{ }^{13}$ Researchers from Public Health
England and collaborating institutions sensibly pushed to publish their study findings before the government committed to buying a million of these tests but were blocked by the health department and the prime minister's office. ${ }^{14}$ Why was it important to procure this product without due scrutiny? Prior publication of research on a preprint server or a government website is compatible with The BMJ's publication policy. As if to prove a point, Public Health England then unsuccessfully attempted to block The BMJ's press release about the research paper.

Politicians often claim to follow the science, but that is a misleading oversimplification. Science is rarely absolute. It rarely applies to every setting or every population. It doesn't make sense to slavishly follow science or evidence. A better approach is for politicians, the publicly appointed decision makers, to be informed and guided by science when they decide policy for their public. But even that approach retains public and professional trust only if science is available for scrutiny and free of political interference, and if the system is transparent and not compromised by conflicts of interest.

Suppression of science and scientists is not new or a peculiarly British phenomenon. In the US, President Trump's government manipulated the Food and Drug Administration to hastily approve unproved drugs such as hydroxychloroquine and remdesivir. ${ }^{15}$ Globally, people, policies, and procurement are being corrupted by political and commercial agendas. ${ }^{16}$

The UK's pandemic response relies too heavily on scientists and other government appointees with worrying competing interests, including shareholdings in companies that manufacture covid-19 diagnostic tests, treatments, and vaccines. ${ }^{17}$ Government appointees are able to ignore or cherry pick science-another form of misuse-and indulge in anti-competitive practices that favour their own products and those of friends and associates. ${ }^{18}$

How might science be safeguarded in these exceptional times? The first step is full disclosure of competing interests from government, politicians, scientific advisers, and appointees, such as the heads of test and trace, diagnostic test procurement, and vaccine delivery. The next step is full transparency about decision making systems, processes, and knowing who is accountable for what.

Once transparency and accountability are established as norms, individuals employed by government should ideally only work in areas unrelated to their competing interests. Expertise is possible without competing interests. If such a strict rule becomes impractical, minimum good practice is that people 
with competing interests must not be involved in decisions on products and policies in which they have a financial interest.

Governments and industry must also stop announcing critical science policy by press release. Such ill judged moves leave science, the media, and stock markets vulnerable to manipulation. Clear, open, and advance publication of the scientific basis for policy, procurements, and wonder drugs is a fundamental requirement. ${ }^{19}$

The stakes are high for politicians, scientific advisers, and government appointees. Their careers and bank balances may hinge on the decisions that they make. But they have a higher responsibility and duty to the public. Science is a public good. It doesn't need to be followed blindly, but it does need to be fairly considered. Importantly, suppressing science, whether by delaying publication, cherry picking favourable research, or gagging scientists, is a danger to public health, causing deaths by exposing people to unsafe or ineffective interventions and preventing them from benefiting from better ones. When entangled with commercial decisions it is also maladministration of taxpayers' money.

Politicisation of science was enthusiastically deployed by some of history's worst autocrats and dictators, and it is now regrettably commonplace in democracies. ${ }^{20}$ The medical-political complex tends towards suppression of science to aggrandise and enrich those in power. And, as the powerful become more successful, richer, and further intoxicated with power, the inconvenient truths of science are suppressed. When good science is suppressed, people die.

Competing interests: I have read and understood BMJ policy on declaration of interests and have no relevant interests to declare.

Provenance and peer review: Commissioned; not externally peer reviewed.

1 Geoghegan P. Cronyism and clientelism. London Review of Books 2020 Nov 5. https://www.lrb.co.uk/the-paper/v42/n21/peter-geoghegan/cronyism-and-clientelism

2 Scally G, Jacobson B, Abbasi K. The UK's public health response to covid-19. BMJ 2020;369:m1932. doi: 10.1136/bmj.m1932 pmid: 32414712

3 lacobucci G. Pandemic preparedness: Government must release 2016 report, says information commissioner. BMJ2020;371:m3953. doi: 10.1136/bmj.m3953 pmid: 33046458

4 Department of Health and Social Care. Policy paper. Annex B: Exercise Cygnus report. 5 Nov 2020. https://www.gov.uk/government/publications/uk-pandemic-preparedness/exercise-cygnusreport-accessible-report

5 Public Health England. Disparities in the risk and outcomes of COVID-19. 2020. https://assets.publishing.service.gov.uk/government/uploads/system/uploads/attachment_data/file/908434/Disparities_in_the_risk_and_outcomes_of_COVID_August_2020_update.pdf

6 Khunti K, Platt L, Routen A, Abbasi K. Covid-19 and ethnic minorities: an urgent agenda for overdue action. BM/2020;369:m2503. doi: 10.1136/bmj.m2503 pmid: 32576558

7 Horton R. Tweet, 15 Oct 2020. https://twitter.com/richardhorton1/status/1316711967554506753

8 Boseley S. Antibody tests bought by UK government "less accurate than maker claims." Guardian 2020 Nov 12. https:/www.theguardian.com/world/2020/nov/12/covid-antibody-test-boughtuk-government-less-accurate-than-makers-claim

9 lacobucci G, Coombes R. Covid-19: Government plans to spend f100bn on expanding testing to 10 million a day. BMJ 2020;370:m3520. doi: 10.1136/bmj.m3520 pmid: 32907851

10 lacobucci G. Covid-19: mass population testing is rolled out in Liverpool. BMJ2020;371:m4268. doi: 10.1136/bmj.m4268 pmid: 33144291

11 lacobucci G. Covid-19: rapid test missed over $50 \%$ of positive cases in Manchester pilot. BMJ 2020;371:m4323. doi: 10.1136/bmj.m4323 pmid: 33158908

12 Mulchandani R, Jones HE, Taylor-Phillips S, etalEDSAB-HOME and COMPARE Investigators. Accuracy of UK Rapid Test Consortium (UK-RTC) "AbC-19 Rapid Test" for detection of previous SARS-CoV-2 infection in key workers: test accuracy study. BM/2020;371:m4262.pmid: 33177070

13 Gill D, Ponsford MJ. Testing for antibodies to SARS-CoV-2. BMJ 2020;371:m4288. doi: 10.1136/bmj.m4288

14 Armstrong S. Covid-19: Government buried negative data on its favoured antibody test. BM 2020;371:m4353. doi: 10.1136/bmj.m4353

15 Cohen K, Kupferschmidt K. The "very, very bad look" of remdesivir, the first FDA-approved COVID-19 drug. Science 2020 Oct 28. https:/www.sciencemag.org/news/2020/10/very-verybad-look-remdesivir-first-fda-approved-covid-19-drug

16 Transparency International. Corruption and covid-19-the story so far. 8 Jul 2020. https://www.transparency.org.uk/corruption-coronavirus-covid-19-latest
17 Ennals E. Government test tsar has $£ 770,000$ shares in drugs firm that sold us $£ 13$ million of "pointless" antibody screening kits-after it emerged that Sir Patrick Vallance has a financial interest in company racing to find vaccine. Daily Mail 2020 Sep 26. https://www.dailymail.co.uk/news/article-8776339/Test-tsar-770-000-shares-firm-sold-13million-pointless-antibody-screening-kits.html

18 Armstrong S. Covid-19: Government faces legal action over $\mathrm{f} 75 \mathrm{~m}$ contract for antibody tests. BMJ 2020;371:m4427. doi: 10.1136/bmj.m4427

19 Mahase E. Covid-19: Vaccine candidate may be more than $90 \%$ effective, interim results indicate. BMJ2020;371:m4347. doi: 10.1136/bmj.m4347 pmid: 33168562

20 Bollyky TJ, Kickbusch I. Preparing democracies for pandemics. BMJ2020;371:m4088. doi: 10.1136/bmj.m4088 pmid: 33097482

This article is made freely available for use in accordance with BMJ's website terms and conditions for the duration of the covid-19 pandemic or until otherwise determined by BMJ. You may use, download and print the article for any lawful, non-commercial purpose (including text and data mining) provided that all copyright notices and trade marks are retained. 